\title{
THE EFFECT OF LONG TERM ADMINISTRATION OF GLUCOCORTICOID TO BONE LINING CELLS APOPTOSIS
}

\author{
Gadis Meinar Sari \\ Department of Physiology, Faculty of Medicine, Universitas Airlangga, Surabaya
}

\begin{abstract}
ABSTRAK
Glukokortikoid banyak digunakan dalam pengobatan sistem kekebalan tubuh atau sebagai terapi peradangan. Namun pemberian jangka panjang dapat menyebabkan efek samping yang membahayakan jiwa. Salah satunya adalah hilangnya massa tulang yang meningkatkan risiko patah tulang. Bone lining cell yang berasal dari sel induk mesenchymal, berfungsi sebagai sel cadangan pembentuk osteoblas. Glukokortikoid bekerja langsung pada osteoblas, bila bone lining cell sel berkurang karena peningkatan apoptosis maka sel cadangan untuk pembentukan tulang akan menurun. Tujuan dari penelitian ini adalah untuk menghitung jumlah bone lining cell apoptosis setelah pemberian glukokortikoid jangka panjang. Penelitian ini menggunakan tikus putih Rattus norvegicus betina berusia 3 bulan yang dibagi menjadi 3 kelompok, setiap kelompok terdiri dari 7 ekor tikus. Kelompok tersebut adalah (1) kelompok kontrol; (2) kelompok perlakuan 1 diberi glukokortikoid 0,01 mg/hari; (3) kelompok perlakuan 2 diberi glukokortikoid 0,2 mg/hari. Perlakuan dilakukan selama 4 minggu dan pada akhir perlakuan tikus dikorbankan dan dilanjutkan dengan preparasi. Jumlah bone lining cell yang mengalami apoptosis dihitung melalui pemeriksaan jaringan tulang femur bagian metafisis menggunakan teknik imunohistokimia. Semua data dianalisis dengan analisis statistik Anova. Hasil penelitian menunjukkan bahwa jumlah bone lining cell apoptosis meningkat pada kelompok dengan pemberian glukokortikoid 0,01 mg/hari dan 0,2 mg/hari dibandingkan dengan kelompok kontrol dengan $p=0,000(p<0,05)$. Jumlah bone lining cell apoptosis pada kelompok dosis glukokortikoid 0,2 mg/hari lebih tinggi daripada kelompok glukokortikoid dosis 0,01 mg/hari dengan p =0,000 (p <0,05). Jadi, pemberian glukokortikoid jangka panjang meningkatkan apoptosis bone lining cell. (FMI 2016;52:251-257)
\end{abstract}

Kata kunci: bone lining cell, apoptosis, glukokortikoid

\begin{abstract}
Glucocorticoid is widely used in medical treatment as an immune system or an inflammation therapy. However its long term administration can cause life-threatening side effects. One of them is bone mass loss which increases the risk of bone fractures in the long-term use. Bone lining cells derived from mesenchymal stem cells, which serve as a backup cell bone-forming osteoblasts. Glucocorticoids acting directly on osteoblasts, bone lining cells when reduced due to increased apoptosis, the reserve cells to bone formation will be decreased. The aim of this study was to count the amount of apoptotic bone lining cells after long term glucocorticoid administration. This study used Rattus norvegicus females aged 3 months that were divided into 3 groups, each group consisted of 7 rats. The groups are: (1) control group; (2) treatment group 1 were given glucocorticoid 0.01 mg/day; (3) treatment group 2 were given glucocorticoid $0.2 \mathrm{mg} /$ day. The treatment carried out for 4 weeks and at the end of treatment, rats were sacrified and continued with preparation, and the number of bone lining cells that undergoing apoptosis was calculated through examination of the femur bone tissue metaphysis section using immunohistochemical technique. All data were analyzed with statistical analysis Anova. The result showed that the number of apoptotic bone lining cells increased in group with glucocorticoid administration 0.01 $\mathrm{mg} /$ day and $0.2 \mathrm{mg} /$ day compared to control group with $p=0.000(p<0.05)$. The number of apoptotic bone lining cells on the group of glucocorticoid dose $0.2 \mathrm{mg} /$ day higher than the group of glucocorticoid dose $0.01 \mathrm{mg} /$ day with $p=0.000(p<0.05)$. In conclusion, long term glucocorticoid administration increase apoptosis of bone lining cells. (FMI 2016;52:251-257)
\end{abstract}

Keywords: Bone lining cells, apoptosis, glucocorticoid

Correspondence: Gadis Meinar Sari, Department of Physiology, Faculty of Medicine, Universitas Airlangga, Jl Mayjend Prof Dr Moestopo 47, Surabaya 60131. Ph0ne: +6231-503261. e-mail: sarigadis@ yahoo.co.id

\section{INTRODUCTION}

Glucocorticoid is produced and secreted by adrenal gland in response to stress and regulates some tissue physiological processes. Among them, this hormone both brings about immunosuppression and antiinflammation and influences apoptosis of some particular cells such as T-lymphocytes and monocytes.
Due to its features, glucocorticoid is widely used in medical treatment as an immune system or an inflammation therapy. Glucocorticoid therapy can save many lives, however its long term administration can cause life-threatening side effects, one of them is bone mass loss which increases the risk of bone fractures (Adler 2003, Dvorak 2006). 
Epidemiologic data suggests that glucocorticoid therapy can double the risk of femur and distal radius fractures and even four times higher risk for spine fractures. The main reason for that is the fact that long term glucocorticoid therapy can induce rapid and severe bone loss which eventually heightens the risk of fractures. An analysis of General Practice Research Database (UK) at Veterans Affair Medical Centers shows that $40 \%$ of respiratory patients who underwent glucocorticoid therapy with daily dosage addition were facing a relative increased risk of femur and spine fractures (Abu 2000, Adler 2003, Takuma 2003, Jia 2006, Kim 2006, Swanson 2006, Lu 2007).

Osteoporosis is a bone disorder caused by imbalance of bone formation by osteoblast and bone resorption by osteoclast or as known as imbalanced bones remodeling that creates the loss of bone mass and the change of bone microarchitecture. These cause bones to become weak and brittle due to bone strength reduction that will lead to an increased fracture risk especially on spine, femur, ankle, radius, and pelvic. Globally, osteoporoticinduced fractures evoked approximately 5.8 million of disablement in 2000 and increased mortality rate. Among risk factors for osteoporosis is oral glucocorticoid intake at $1 \%$ of population and $25 \%$ of patients above 75 years old. Glucocorticoid-induced osteoporosis can cause serious problems in societies with high elderly population growth and is multiplied because of high life expectancy along with increased community health status. In Developed countries, such as The US, osteoporosis tops the list of major health problems suffered by 10 million people above 50 years old. Fifty percent of female population and over $20 \%$ of male population above 50 will suffer bone fractures during their lives, composing 1.5 million of bone fractures every year. Osteoporosis-induced bone fractures happen to 1 of every 2 women and 1 of every 5 men above fifty, spending $£ 1.8$ billion in the UK only and over $€ 30$ billion across Europe each year for health services (McNamara 2010).

Bones are special connective tissues that form organ systems and tissues, bones function as a part of locomotor system, protection and mineral homeostasis. Bones consist of four different cells: osteoblasts, osteocytes, bone lining cells, and osteoclasts. Bone lining cells are rooted from mesenchymal stem cells or osteoprogenitor cells, which is an inactive form of osteoblasts known as "resting osteoblasts". A study reported that bone lining cells might be an osteoblast precursor that regulates crystal growth of bone mineral or a barrier between extracellular fluid and bone (Downey 2006, Datta 2008, Lorenzo 2008, Bonewald 2011).
Glucocorticoid works directly on bone forming cells through glucocorticoid receptor $(\mathrm{GR} \alpha)$ at bone forming surface, where bone remodeling takes place (Abu 2000). Increasing number of glucocorticoid-induced osteoporosis in recent years suggests that there have been an increase in osteocytes and osteoblasts apoptosis. This pro-apoptotic effect is a direct impact of steroid on osteoblast-lineage cells as shown in previous studies about osteocytes and osteoblast culture cells (Plotkin 2007). Glucocorticoid modulates intracellular Pyk2 kinase activities. Proline-rich tyrosine kinase 2 or related adhesion focal tyrosine kinase, and cellular adhesion kinase $\beta$ or calcium-dependent tyrosine kinase are members of focal adhesion kinase (FAK) from nonreceptor tyrosine kinase family. Despite to the fact that Pyk2 and FAK are very homologue, these proteins are showing different effects on cells. FAK activation causes cell multiplication and defense, while Pyk2 activation causes cytoskeleton reorganization, cell damage, and apoptosis (Hofbauer 1999, Nakamura 2003, Park 2004, Plotkin 2007).

Every organ gets its reserve cells from stem cells, such as muscle satellite cells, basal cells, and lining cells in bones ("resting cells" of osteoblast). If there is a damage or apoptosis on the reserve cells, any manipulations will not be able to fix them, causing a decrease in the number of the cells. The same case happens in bones, if the number of bone lining cells is decreasing due to apoptosis, there will be insufficient number of reserve cells for bone formation, leading to higher risk of osteoporosis.

There have been many studies about glucocorticoid effect on bones, yet none of them revealed the molecular mechanism that underlying the initial process of bone formation reduction by illustrating the increase of apoptosis on bone lining cells. Based on the fact, this study is aimed to prove whether long term external glucocorticoid administration will increase apoptosis on bone lining cells that will lead to higher risk of osteoporosis.

\section{MATERIALS AND METHODS}

This is an experimental research to analyze the causeeffect relationship of treatments and results in a particular period of time. Three-month old female rats (Rattus norvegicus strain Wistar) were used as experimental units. Total sample was 21 rats divided into three groups, control group, treatment group 1 with low dose administration of glucocorticoid $(0.01 \mathrm{mg} / 200$ gram of weight/day), treatment group 2 with high dose administration of glucocorticoid $(0.2 \mathrm{mg} / 200$ gram of weight/day). The treatment was carried out in 4 weeks 
and at the end of the week rats were sacrificed to be taken the femurs and continued with preparation for immunohistochemical staining. Next, the number of lining cells that are undergoing apoptosis was counted; these cells were marked by nucleus condensation and chromatin fragmentation that can be seen through immunohistochemical examination (Weinstein 2000), and were microscopically counted per field of view.

\section{RESULTS}

The collected data were the number of bone lining cells undergoing apoptosis due to low dose administration of glucocorticoid $0.01 \mathrm{mg} / 200 \mathrm{gr}$ and high dose administration of glucocorticoid $0.2 \mathrm{mg} / 20$. gr after 4 weeks of treatment, the number was calculated through examination of the femur bone tissue metaphysis section using immunohistochemical technique. The higher the dose of glucocorticoid, the higher number of cells undergoing apoptosis. This variable was analyzed with statistical analysis Anova, to see the effects of treatments among different groups toward dependent variable. The results of analysis of variance showed a considerable difference, $\mathrm{p}=0.000 \quad(\mathrm{p}<0.05)$. Multiple Comparisons in Post Hoc Test was run to know which group showed the difference, and the results are shown in table 1.

Table 1. Apoptosis cell variable multiple comparisons among different groups.

\begin{tabular}{lcl}
\hline & Groups & $\mathrm{p}$ \\
\hline Control & Dosage $0.01 \mathrm{mg}$ & 0.000 \\
& Dosage $0.2 \mathrm{mg}$ & 0.000 \\
Dosage $0.01 \mathrm{mg}$ & Dosage $0.2 \mathrm{mg}$ & 0.000 \\
\hline
\end{tabular}

Based on table 1, the results of Multiple Comparisons showed differences among control group and dosage $0.01 \mathrm{mg}$ group, $\mathrm{p}=0.000(\mathrm{p}<0.05)$, and dosage $0.2 \mathrm{mg}$ group, $p=0.000 \quad(p<0.05)$. Similar result also seen between dosage $0.01 \mathrm{mg}$ group, $\mathrm{p}=0.000(\mathrm{p}<0.05)$, and dosage $0.2 \mathrm{mg}$ group, $\mathrm{p}=0.000(\mathrm{p}<0.05)$. The average results of bone lining cells undergoing apoptosis is shown in Fig. 1.

Analysis of the graphic showed that dosage $0.2 \mathrm{mg}$ group has higher average apoptosis cells than control group and dosage $0.01 \mathrm{mg}$ group. Similarly, dosage 0.01 mg group has higher average apoptosis cells than control group.

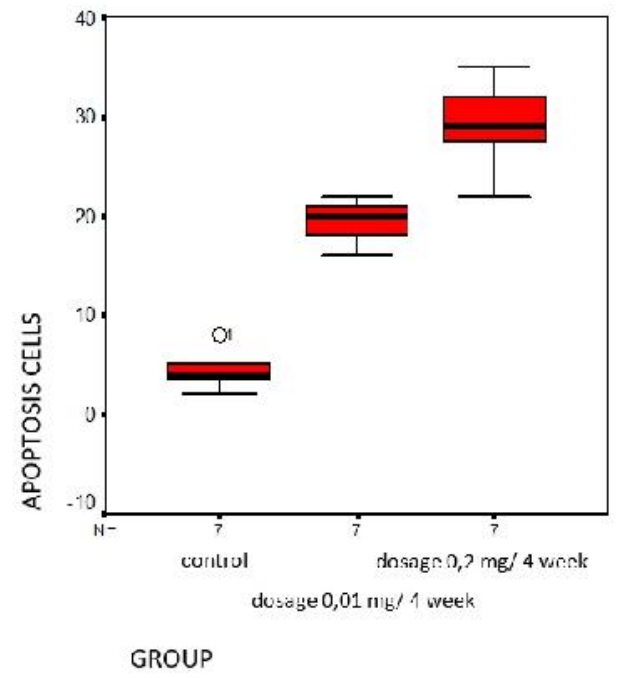

Fig. 1. Average of group apoptosis cells

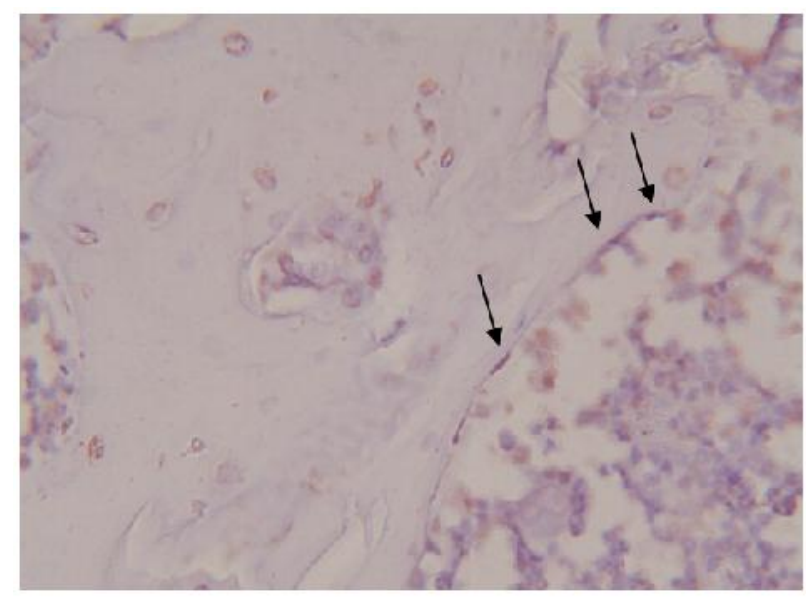

Fig. 2. Lining cells in the control group (magnified 400x)

\section{DISCUSSION}

This study was aimed to analyze the cause-effect relationship between treatments and results of treatments after a period of time. Treatments given to experimental animals in this study used glucocorticoid medication, that is Dexamethasone, in two variations of dosage, low dose intake $0.01 \mathrm{mg} / 200 \mathrm{gr}$ of weight, and high dose intake $0.2 \mathrm{mg} / 200 \mathrm{gr}$ of weight based on conversion table of doses calculation from various animals and human. Dexamethasone used in this study is a common, cheap, and accessible glucocorticoid medication that is often used in therapy for chronic patients. Weinstein (2000), mentioned that bone damage often occurs to $25 \%$ patients with glucocorticoid 
therapy. Even if prior to the therapy, patients are observed having femoral head collapse and severe osteoporosis, they fail to lower the dose or stop the therapy due to the vast need of the glucocorticoid therapy for transplant, lung diseases, rheumatic, autoimmune, haemopoietic, and gastrointestinal patients. As a consequence, patients will receive glucocorticoid therapy in months, years, or their whole lives.

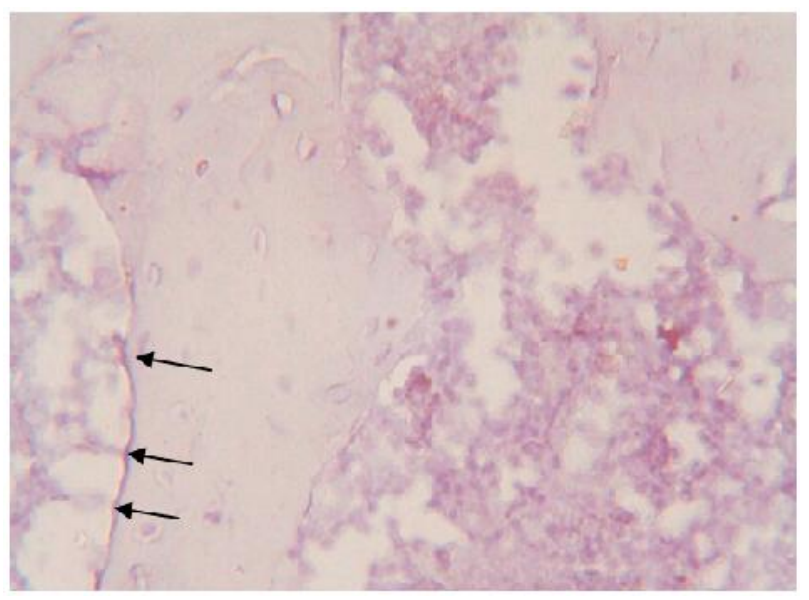

Fig. 3. Lining cells apoptosis in the treatment group of glucocorticoid 0,01 mg dosage (magnified 400x)

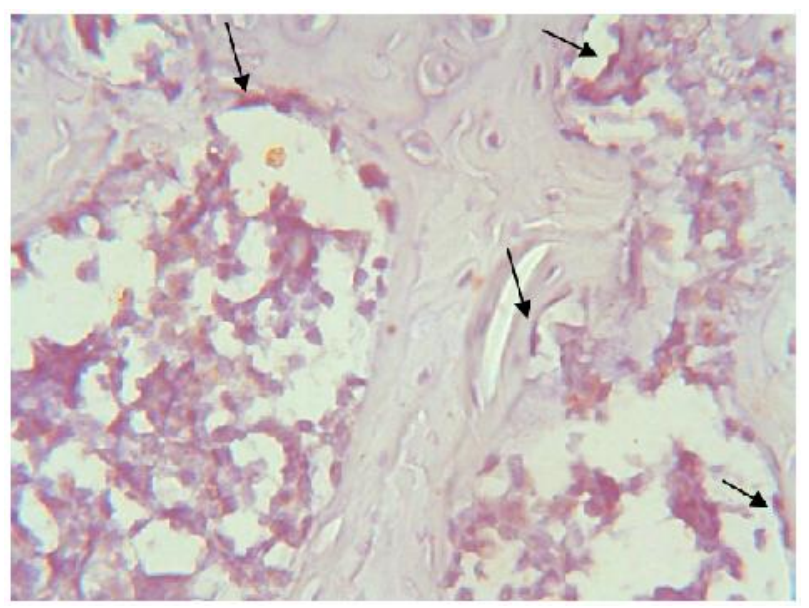

Fig. 4. Lining cells apoptosis in the treatment group of glucocorticoid 0,2 mg dosage (magnified 400x).

The risk of bone impairment has increased as the more dosage is taken and the more long term therapy is given. In this study, glucocorticoid is administered for the period of 4 weeks. Suatmadji (2001) suggests that rats administered with glucocorticoid within 4 weeks, is equal to the period of 3 to 4 years in human body, showed the reduction in its bone mineral density associated with the amount of osteoblast, progenitor in the bone marrow, and the dramatic drop of cancellous bone area and trabecular (Suatmadji 2001). Those changes are due to the significant drop in osteoid area and the decrease of mineral apposition and the bone formation. Glucocorticoid affects the bone impairment through fat emboli, vascular tamponade in caput femur blood vessels through fat retention or bone marrow liquid. Another possibility is cell termination program or apoptosis which is part of bone impairment mechanism. Weinstein reported that rats which were induced with glucocorticoid for 4 week-period showed the increase of apoptosis osteoblast three times bigger in the area of cancellous vertebrae bone and $28 \%$ of apoptosis osteocyte in cortical bone metaphysis. The examination of lining cells apoptosis using immunehistochemical method through tunnel assay (Terminal deoxyridine nucleotide end labelling assay), an advancement of apoptosis examination method through DNA fragmentation, shed light to the detection of apoptosis through the ordinary staining of hematoxylin eosin protocol. The DNA fragment is detected through the enzymatic labelling from the edge of $3{ }^{\circ} \mathrm{OH}$ nucleotide. The edge of DNA fragment is mostly detected in the nucleotide which is afflicted by apoptosis and in the apoptotic bodies. Tunnel assay makes it possible to detect the early stage of apoptosis since the DNA fragmentation occurring before the morphologic changes is evident in the histologic specimen. Cell apoptosis is likely to occur in groups close to the normal cell, in which cell with nucleotide condensation and chromatic fragmentation are observable (Weinstein 2000). The calculation of the number of lining cell apoptosis in this study is examined in the area of caput femur bone tissues. Only after the specimen of femur tissues are made as in appendix 10, the calculation of lining cells afflicted by apoptosis is ready to be done.

The animal's body part to examine is the femur metaphysis part. Each kind of bone constitutes cortical and trabecular in a particular proportion depending on the type of the bones. In general bones have more trabecular than cortical bones with wider surface so that their metabolic activities are bigger. As a result, trabecular bones are likely to experience more changes so that they tend to lose their mass. This change is one of the causes why vertebrae bones, column femur and the area of long bone metaphysis, are the most likely area to have fracture in people suffering from osteoporosis. The study shows that those bones are significant in terms of their structure variance and the density of bone tissues. Hence, the study is focusing in the area of femur metaphysic, the femur area close to column femur. This particular area has more trabecular 
than cortical bones which have higher metabolism so that it is easy to observe the metabolic changes of the bone cells. In general, dark-skinned males have higher bone density compared to females. Meanwhile, it is stated that the basal glucocorticoid (corticosterone) rate in female human and animal is higher than in that of male. For that reason, this study uses female rats since they have similar metabolism with human. The rats used in the experiment are 3 months old, an adult age for animal, due to the fact that adult rat has lower influence in its growth hormone compared to the period before adult, so that the bone growth is not really affected.

Weinstein (2000) argued that long term glucocorticoid treatment will cause osteoblast apoptosis to people suffering from osteoporosis. Osteoblast is the cells that secrete organic matrix, an area where calcium phosphate crystal (hydroxyapatite) is deposited, such as in collagen, which play role in determining the bone density (Sherwood 2010). On the other hand, Downey and Siegel (2006) stated that Osteoblast, Osteocyte, and lining cells are rooted from mesenchymal stem cell or widely known as osteopregenitor (6). In addition it is mentioned that osteoblast will move through three channels to form three outcomes, (1) active osteoblast (2) surrounded by matrix to become osteocyte or (3) become relatively inactive and form the lining cells. Based on the above statement, a long term glucocorticoid treatment may also possible to lining cells as both osteoblast and lining cells are rooted from the similar source. This study proves a long term glucocorticoid treatment may cause apoptosis process in lining cells. Lining cells look as a flattened, thin, elongated cell covering most of the surface of mature bone. The cytoplasm protuberance or its gap junctions are connected one another or with osteocytes. Since lining cells have inactive metabolism, they contain fewer organelle and cytoplasm than osteoblasts. There will be time when lining cells become resting osteoblasts or surface osteocytes (Downey 2006). Based on this assumption, this study has its significance as lining cells the resource cells for osteoblasts. The long term glucocorticoid therapy causes osteoblast and osteocyte apoptosis (Weinstein 2000), and it is also proven in this study that it may worsen the bone density. Other researcher suggests that lining cells are the osteoblast precursors which regulate the growth of bone crystal (hydroxyapatite) hence when the lining cells apoptosis increases as a result of long term glucocorticoid therapy, the bone density will decrease (Downey 2006).

The previous study showed that glucocorticoid works directly on bone forming cell (osteoblastic lineage) through glucocorticoid receptor $(\mathrm{GR} \alpha)$ on the bone forming surface, in which remodeling of osteocyte and osteoblast takes place (Abu 2000). Glucocorticoid modulates the intracellular activities of proline-rich tyrosine kinase 2, a strand of Focal adhesion kinase (FAK) from the non-receptor tyrosine kinase family. Despite their homologous, Pyk2 and FAK proteins give distinctive effect on cells. The activation of FAK leads to the multiplication and the defense of cells, whereas Pyk2 affects the cytoskeleton reorganization, cell damage and apoptosis (Park 2004, Plotkin 2007). When cell damage and apoptosis occur, any manipulations will not be able to fix it causing the decrease in the number of cells. Similarly, this also applies to the bones, if the number of bone lining cells is decreasing due to apoptosis, there will be insufficient number of reserve cells for bone formation, leading to higher risk of osteoporosis.

\section{CONCLUSION}

A long-term glucocorticoid therapy will increase apoptosis of the bone lining cells.

\section{REFERENCES}

Abu EO, 2000. The Localization of the Functional Glucocorticoid Receptor $\alpha$ in Human Bone. The Journal of Clinical Endocrinology \& Metabolism, Vol. 85, No. 2, pp.883-889.

Bergmann P, Body JJ, Boonen S, Boutsen Y, Devogelaer JP, Goemaere S, Kaufman J, Reginster JY, and Rozenberg S, 2011. Review Article Loading and Skeletal Development and Maintenance. Journal of Osteoporosis. Volume 2011, pp. 1-16.

Bonewald LF, 2011. Review: The Amazing Osteocyte. Journal of Bone and Mineral Research, Vol. 26, No. 2, February 2011, pp. 229-238.

Adler RA, 2003. Suggested Guidelins for Evaluation and Treatment of Glucocorticoid-Induced Osteoporosis for [3] Baron R, 2006. Anatomy and Ultrastructur of Bone Histogenesis, Growth and Remodeling. http://www.endotext.org.

Baron R, 2006. Anatomy and Ultrastructur of Bone Histogenesis, Growth and Remodeling. http://www. endotext. org.

Datta HK, Ng WF, Walker JA, Tuck SP, Varanasi SS, 2008. The cell biology of bone metabolism. J. Clin. Pathol: 61: 577-587

Donatus dan Nurlaila, 1986. Obat tradisional dan Fitoterapi, uji toksikologi. Fakultas Farmasi Universitas Gajah mada Yogyakarta, hlm. 3-11.

Downey PA, Siegel MU, 2006. Bone Biology and the Clinical Implications for Transcriptional Activator of Osteoblast Differentiation. Cell, Vol. 89, pp. 747-754. 
Dvorak J, 2006. Glucocorticosteroids in football: use and misuse. British Journal of Sports Medicine; 40(supplement 1): 148-154.

Galli C, 2008. Targeted Deletion of a Distant Transcriptional Enhancer of the Receptor Activator of Nuclear Factor-kB Ligand Gene Reduces Bone Remodeling and Increases Bone Mass. Endocrinology 149(1): 146-153.

Ganong WF, 2005. Review of Medical Physiology. The McGraw-Hill Companies, Inc. USA. Pp. 342-380.

Garcia AJ, Rayes CD, 2005. Bio-adhesive Surface to Promote Osteoblas Differentiation and Bone Formation. J of Dental Research, Vol84, No. 5, pp. 407-413.

Guo Y, 2002. Caspase-2 Induces Apoptosis by Releasing Proapoptotic Proteins from Mitochondria. The Journal of Biological Chemistry, Vol. 277, No. 16, pp. 1343013437.

Guyton AC, 2011. Textbook of Medical Physiology. WB Saunders Company.

Handojo I, 2003. Pengantar Imunoasai Dasar. Airlangga University Press.

Handojo I, 2008. Imunoasai dari Sitokin (Cytokine), Hand out kuliah. Bagian Patologi Klinik, FK Unair/Dr.Soetomo, Surabaya.

Hofbauer LC, 1999. Stimulation of Osteoprotegerin Ligand and Inhibition of Osteoprotegerin Production by Glicocorticoids in Human Osteoblastic Lineage Cells: Potential Paracrine Mechanisms of Glucocorticoid-Induced Osteoporosis. Endocrinology, Vol. 140, No. 10, pp.4382-4388.

Jia D, 2006. Glucocorticoids Act Directly on Osteoclasts to Increase Their Life Span and reduce Bone Density. Endocrino;ogy 147(12): 5592-5599.

Kaniawati M, 2005. Biochemical Markers of Bone Turnover. The 2nd National Congress Indonesian Osteoporosis Association, Surabaya.

Klein-Nulend J, Bakker AD, Bacabac RG, Vatsa A, Weinbaum S, 2013. Review: Mechanosensation and transduction in osteocytes

Bone 54 (2013) pp. 182-190.

Kumar V, Abbas AK and Fausto N, 2005. Robbins and Cotran Pathologic Basic of Disease, 7th ed. China: Elsevier Saunders, pp. 26-106.

Kim HJ, 2006. Glucocorticoids suppress bone formation via the osteoclast. The Journal of Clinical Investigation, volume 116, Number 8. pp. 2152-2160.

Kondo H, 2005. Unloading Induces Osteoblastic Cell Suppression and Osteoclastic Cell Activation to Lead to Bone Loss via Sympathetic Nervous System. The journal of Biological Chemistry, Vol.280, No. 34, pp. 30192-30200. the Departement of Veteran Affairs. Arch Intern Med, Vol. 163, pp. 2619-2624.

Lane NE, 2006. Glucocorticoid-Treated Mice Have Localized Changes in Trabecular Bone Material Properties and Osteocyte Lacunar Size That Are Not
Observed in Placebo-Treated or Estrogen-Deficient Mice. J Bone Miner Res. 21(3): pp. 466-476.

Lorenzo J, Horowitz M, Choi Y, 2008. Osteoimmunology: Interactions of the Bone and Immune System. Endocrine Reviews, 29(4): 4003-440.

Losel RM, 2003. Nongenomic Steroid Actin: Controversies, Questions, and Answers. Physiol Rev 83: 9651016.

Lu NZ, 2007. Selective regulation of Bone Cell Apoptosis by Translational Isoforms of the Glucocorticoid Receptor. Molecular and calluler Biology, Vol. 27, No. 20, pp. 7143-7160.

Manolagas SC, 2000. Birth and Death of Bone Cells: Basic regulatory Mechanisms and Implications for the Pathogenesis and Treatment of Osteoporosis. Endocrine Reviews 21(2): 115-137.

Manolagas SC, 2002. Sex Steroid and Bone. Recent Progress in Hormone Research. 57: 385-409.

McNamara LM, 2010. Review: Perspective on postmenopausal osteoporosis: establishing an interdisciplinary understanding of the sequence of events from the molecular level to whole bone fractures. J. R. Soc. Interface 7, pp. 353-372.

Nakamura, 2003. Osteoprotegerin Regulates Bone Formation trough Coupling Mechanism with Bone Resorpsion. Endocrinology Vol. 144 (12), pp. 54415449.

Owen GRH, 2005. Focal Adhesion Quantification - A New Assay of material Biocompatibility. European Cell and Material 9: 85-96.

Park SY, Avraham S, 2004. RAFTK/Pyk2 Activation Is Mediated by Trans-acting Autophosphorylation in a Src-independent Manner. The Journal of Biological Chemistry Vol. 279, No. 32, pp. 33315-33322.

Plotkin LI, 2005. Mechanical Stimulation prevents osteocyte apoptosis: requirement of integrins, Src kinases, and ERKs. Am J Physiol Cell Physiol 289: C633-C643.

Plotkin LI, 2007. Glucocorticoids Induce Osteocyte Apoptosis by Blocking Focal Adhesion Kinasemediated Survival. The Journal of Biological Chemistry, Vol. 282, No. 33, pp. 24120-24130.

Raison, CL, 2003. When Not Enough Is Too Much: The Role of Insufficient Glucocorticoid Signaling in the Pathophysiology of Stress-Related Disorders. Am J Psychiatry, 160:1554-1565

Raisz GL, 2005. Pathogenesis of osteoporosis: Concept, Conflicts, and Prospect. J.Clin.Invest. 115: 33183325.

Riggs BL, Khosla S,and Melton JL, 2002. Sex steroid and The Construction and Conservation of the Adult Skeleton. Endocrinology Reviews 23(3): 279-302.

Seibel MJ, 2005. Biochemical Markers of Bone Turnover Part I: Biochemistry and Variability. Clin Biochem Rev 26: 97-116. 
Sherwood L, 2010. Human Physiology From Cells to Systems. Australia: Thomson, pp. 769.

Suatmadji DW, 2001. Pathogenesis of Steroid-Induced Osteoporosis. Naskah lengkap Simposium Asma \& Osteoporosis. PDPI Cabang Malang/RSUD Dr Saiful Anwar. Pp. 41-55

Swanson, 2006. Glucocorticoid Regulation of Osteoclast Differentiation and Expression of Receptor Activator of Nuclear Factor-kB (NF-kB) in Mouse Calvarial Bones. Endocrinology Vol. 147, pp. 36133622 .

Takuma A, 2003. Dexamethasone Enhances Osteoclast Formation Synergistically with Transforming Growth Factor- $\beta$ by Stimulating the Priming of Osteoclast
Progenotirs for Differentiation into Osteoclasts. The Journal of Biological Chemistry, vol. 278, No. 45, pp. 44667-44674.

Udagawa N, 2000. Osteoprotegerin Produced by Osteoblasts Is an Important Regulator in Osteoclast Development and Function. Endocrinology, Vol. 147 (12), pp. 5592-5599.

Watts NB, 1999. Clinical Utility of Biochemical Markers of Bone remodeling Clinical Chemistry 45: 1359-1368.

Weinstein RS, 2000. Apoptosis of Osteocytes in Glucocorticoid-Induced Osteonecrosis of the Hip. The Journal of Clinical Endocrinology \& Metabolism 